\title{
KEBERPIHAKAN MEDIA DALAM PEMILIHAN PRESIDEN 2014
}

\author{
Intan Permata Sari \\ Fakultas Tarbiah dan Tadris, Program Studi Tadris IPS, Institut Agama Islam Negeri Bengkulu \\ Jl. Raden Fatah Pagar Dewa Bengkulu, Kota Bengkulu, Provinsi Bengkulu, 38211, Indonesia \\ No.Telp./HP: 085292917330 \\ E-mail: intanpermata@iainbengkulu.ac.id
}

Naskah diterima pada tanggal 29 Januari 2018, direvisi tanggal 22 Mei 2018, disetujui tanggal 24 Mei 2018

\section{MEDIA'S PARTIALITY IN THE PRESIDENTIAL ELECTION 2014}

\begin{abstract}
The 2014 election results were a major victory for the Indonesian Democratic Party (PDI) of the Struggle after being opposed for ten years. Jokowi's 2014 victory opened big opportunities for him and his party to return to power in the 2019 election. His victory cannot be separated from the news about himself in the media. Online media is in charge of constructing the reader's mind about the ideal leader character for Indonesia. This paper aims to provide an overview of media involvement, especially online media in winning presidential candidates and the discourse/issues they build to show the advantages and cover the shortcomings of their presidential candidates. This article uses a construction analysis approach to reality with text as its object. The results of this study indicate that online media owners play an active role in constructing the presidential choice. This is because of media interests, namely the interests of political practice, ideology, and business. In addition, online news presented to the reader contained subjectivity in order to form a strong character for the presidential candidate. At the same time, this news is used to dismiss the issueldiscourse that harms the candidates.
\end{abstract}

Keywords: media, politics, media reality, elections 2014, online news.

\begin{abstract}
Abstrak. Hasil Pemilu 2014 menjadi kemenangan besar bagi Partai Demokrasi Indonesia (PDI) Perjuangan setelah menjadi oposisi selama sepuluh tahun. Kemenangan Jokowi tahun 2014 membuka peluang yang begitu besar bagi dia dan partainya untuk kembali berkuasa pada Pemilu 2019. Kemenangan Jokowi pada tahun 2014 tidak bisa dilepaskan dari pemberitaan mengenai dirinya di media khususnya media online. Media online bertugas mengonstruksi pikiran pembaca mengenai karakter pemimpin ideal untuk Indonesia. Tulisan ini bertujuan untuk memberikan gambaran keterlibatan media khususnya media online dalam memenangkan calon presiden serta wacana/isu yang mereka bangun guna memperlihatkan kelebihan dan menutupi kekurangan calon presiden mereka. Artikel ini menggunakan pendekatan analisis konstruksi atas realitas dengan teks sebagai objeknya. Hasil penelitian ini menunjukkan bahwa pemilik media online berperan aktif dalam mengonstruksi wacana presiden pilihannya. Ini bukan tanpa sebab karena ada kepentingan yang dibawa oleh media tersebut, yaitu kepentingan politik praktis, ideologis, dan bisnis. Selain itu berita-berita online yang disajikan kepada pembaca mengandung unsur subjektivitas yang tinggi. Hal ini dilakukan guna membentuk karakter yang kuat bagi calon presiden serta di saat yang sama pemberitaan ini digunakan untuk menepis isu/wacana yang merugikan para calon.
\end{abstract}

Kata kunci: media, politik, realitas media, pemilu 2014, berita online. 


\section{PENDAHULUAN}

Pemilihan Presiden (Pilpres) 2019 masih satu tahun lagi. Akan tetapi gejolak dalam masyarakat mengenai sosok yang pantas untuk memimpin Indonesia lima tahun ke depan sudah mulai tampak. Jokowi berada pada posisi yang sangat kuat. Beliau adalah calon presiden yang sudah diusung oleh beberapa partai besar seperti PDIP, Golkar, NasDem, PPP, dan Hanura. Selain itu, posisi beliau sebagai petahana juga sangat menguntungkan. Beliau mampu membuat kebijakan-kebijakan praktis yang mampu mencuri perhatian rakyat sehingga ingin memilihnya kembali. Di sisi lain, Jokowi belum memiliki lawan yang cukup tangguh. Ada beberapa nama yang disinyalir akan menjadi lawan politik Jokowi, sebut saja Prabowo Subianto, Gatot Nurmantyo, dan Agus Harimurti Yudhoyono.

Akan tetapi muncul gerakan dari lawan politik Jokowi yang memviralkan \#2019gantipresiden. Mereka yang memviralkan hal ini menganggap bahwa Jokowi telah gagal memimpin Indonesia selama empat tahun ini. Mereka memberikan fakta-fakta bahwa kebijakan-kebijakan Jokowi ternyata tidak pro kepada masyarakat seperti menarik subsidi listrik, dolar yang terus naik hingga di atas Rp14.000, dan juga kebijakan untuk mempermudah tenaga asing untuk bekerja di Indonesia. \#2019gantipresiden diharapkan mampu mendulang perhatian dan simpati rakyat untuk tidak lagi memilih Jokowi tahun 2019.

Meskipun begitu, politik sangat cair serta dinamis. Pemilu 2014 memberikan pelajaran bahwa politik tidak bisa dihitung secara matematis. Keberpihakan partai pada calon presiden ternyata tidak berpengaruh signifikan. Hal ini dibuktikan dengan kekalahan Prabowo walaupun beliau sudah mengantongi enam partai pendukung (Gerindra, PAN, PKS, Golkar, PPP, dan Partai Bulan Bintang). Dengan keenam partai ini Prabowo-Hatta mengantongi 48,93\% suara atau 292 kursi DPR sedangkan Jokowi hanya mengantongi 39,97\% suara atau 207 kursi DPR dengan didukung oleh empat partai (PDIP, PKB, NasDem, dan Hanura) (Wardah, 2014).
Kemenangan Jokowi tahun 2014 memberikan pemahaman bahwa pemegang kuasa terbesar tetaplah rakyat. Kemenangan dalam pemilu tidak dipengaruhi oleh jumlah kursi di DPR tetapi bagaimana hati rakyat dapat dimenangkan dan suara rakyat dapat tersampaikan. Untuk mendapatkan simpati dari rakyat, calon presiden membutuhkan media untuk memperkenalkan diri, visi, misi, prestasi serta pikiran-pikiran mereka ketika memimpin Indonesia. Hal ini terlihat sama dengan Pemilihan Presiden tahun 2014 yang melibatkan media sebagai agen dalam menyebarkan informasi bagi pembacanya.

Pola pemenangan Capres 2019 sepertinya tidak jauh berbeda dengan tahun 2014, masih akan melibatkan media khususnya media sosial dalam menyebarkan informasi serta hoaks. Pemilihan Presiden tahun 2014, bagi sebagian besar masyarakat Indonesia, mungkin adalah kejadian yang tidak mudah dilupakan begitu saja.

Banyak pihak menilai bahwa 'pertarungan' Calon Presiden tahun 2014 terasa sangat sengit dikarenakan beberapa kondisi. Pertama, hanya ada dua calon presiden yang tampil berlaga sehingga pertandingannya head to head. Kedua, semua calon presiden adalah 'orang baru' dalam pemerintahan Indonesia. Ketiga, ada dukungan yang begitu kuat dari partai politik dan masyarakat sehingga kesempatan keduanya untuk menjadi pemenang hampir sama. Keempat, ada keterlibatan media massa yang luar biasa yang bahkan menyebabkan media massa di Indonesia 'terbelah' menjadi dua, yaitu media massa pendukung Jokowi dan media massa pendukung Prabowo.

Media massa adalah salah satu pihak yang boleh 'dipersalahkan' atas semua kejadian karena media massa memiliki andil dan tanggung jawab yang begitu besar untuk memenangkan calon pilihannya. Media massa tidaklah netral, mereka berpihak (Sudibyo, 2001). Keberpihakan ini bisa dibaca dengan berbagai sisi, tidak hanya semata-mata demi keuntungan perusahaan tetapi ada ideologiideologi yang disembunyikannya demi kepentingan pemilik media massa. Media massa tidak lagi memainkan peranan sebagai agen yang memproduksi dan menyebarkan informasi tetapi juga sebagai aktor yang turut 
menentukan berita mana yang layak atau tidak untuk dikonsumsi oleh masyarakat (Junaedi, 2013).

Seiring dengan perkembangan zaman, media cetak, radio, maupun televisi bukan lagi sumber informasi yang bisa menunjang kebutuhan informasi masyarakat Indonesia yang sangat dinamis. Media-media tersebut dianggap kurang update dalam memberitakan berbagai informasi yang terjadi saat ini. Media cetak hanya bisa menghadirkan berita setiap harinya, radio sudah mulai ditinggalkan orang, sedangkan televisi memiliki keterbatasan waktu untuk menceritakan semua kejadian yang terjadi di dunia saat ini.

Lahirnya media online tidak lain merupakan jawaban bagi masyarakat Indonesia yang sudah memasuki tahap masyarakat postmodern yang salah satunya ditandai dengan "mode informasi" (Lubis, 2014), yakni di era masyarakat postmodern mengorganisasi dan menyebarkan informasi dan hiburan. Media online dianggap sebagai media paling praktis untuk saat ini. Media online bisa diakses kapan saja dan di mana saja. Seseorang bisa membaca berita untuk hari ini sampai beberapa bulan sebelumnya. Praktis, mudah, cepat, gratis, mungkin itu gambaran untuk media online yang menjadi kritik bagi media-media lainnya.

Berita online benar-benar disadari mampu untuk memengaruhi pembaca bahkan dianggap mampu untuk mengubah orientasi politik pembaca. Psikologi masyarakat Indonesia yang cenderung praktis, mereka tidak ingin membaca terlalu banyak dan mereka ingin bebas untuk dapat mengakses informasi kapan pun mereka inginkan. Kecenderungan pembaca ini disadari betul oleh pemilik berita online sehingga dimanfaatkan sebagai media untuk mengonstruksi pikiran pembaca mengenai sosok calon presiden yang mereka dukung. Konstruksi ini dilakukan dengan membangun karakter pemimpin yang baik bagi calon presidennya, menepis isu-isu miring mengenai calon presiden pilihan mereka, dan juga melakukan kampanye negatif untuk lawan politiknya. Semua ini dilakukan dengan wacana serta isu-isu yang mereka hadirkan.
Tulisan ini bertujuan untuk memberikan gambaran mengenai keterlibatan dan keberpihakan media dalam mengonstruksi calon presiden mereka. Wacana-wacana online yang ditulis oleh media, sedikit banyak memberikan pengaruh kepada pembaca. Berita online dimanfaatkan untuk membangun karakter baik bagi kedua calon pemimpin seperti Jokowi selalu dikonstruksikan sebagai sosok yang merakyat, sedangkan Prabowo selalu diberitakan sebagai sosok yang tegas, nasionalis, dan cerdas. Selain itu, berita online juga dimanfaatkan untuk menepis isuisu yang merugikan berbagai pihak seperti pembawaan Jokowi yang merakyat adalah pencitraan semata atau kasus HAM 1998 yang kembali diungkit untuk menjatuhkan Prabowo.

\section{LANDASAN KONSEP}

Media massa memiliki kekuatan yang didukung oleh kerja sama tiga faktor, yaitu, 1) ubiquity; 2) cumulative of message; dan 3) consonance of journalists. Faktor ubiquity atau "serba hadir" berarti bahwa media massa berada di mana-mana dan sulit untuk dihindari oleh khalayak, sehingga media massa mampu mendominasi lingkungan informasi. Faktor cumulative of message atau "kumulasi pesan" terjadi karena pesan media massa yang bersifat kumulatif, dapat memperkuat dampaknya, melalui pengulangan pesan berkali-kali dan penyatuan pesan yang terpotong-potong. Faktor consonace of journalists atau "keseragaman para wartawan" dari berbagai jenis media, menurut Noumann, semakin menambah terpaan dan dampak media massa terhadap khalayak (Arifin, 2014).

Padahal, pada awalnya media merupakan alat untuk mengontrol kekuasaan pemerintah yang berkuasa atau negara sehingga diposisikan sebagai "watch dog" kekuasaan bahkan media diposisikan setara dengan empat pilar demokrasi, yaitu eksekutif, legislatif, dan yudikatif. Media massa diposisikan sebagai pilar keempat dalam demokrasi karena media massa memiliki kekuatan untuk menggerakkan opini 
rakyat sehingga diharapkan kebijakankebijakan pemerintah dapat dikontrol demi kepentingan rakyat (Subiakto \& Ida, 2012).

Media menggunakan kekuatannya untuk membentuk opini publik sehingga mampu untuk memengaruhi kebijakan negara (Syahputra, 2012). Dengan adanya kekuatan untuk membentuk opini publik dengan wacana-wacana yang mereka hadirkan, media tentu memiliki kekuatan yang begitu besar. Seperti yang dikatakan oleh Irwan Abdullah bahwa pemilik kekuasaan bukan lagi pemilik teknologi tetapi pemilik informasi. Dengan kekuatan yang begitu besar, media memiliki kekuatan untuk mengontrol negara, meskipun di saat yang sama bertindak sebagai wakil public interest (Syahputra, 2012).

Media sebagai salah satu sumber berita memiliki kebebasan untuk menyampaikan realitas yang terjadi dalam masyarakat. Meskipun begitu, kebebasan yang dimiliki media bukanlah kebebasan yang betul-betul bebas tetapi masih terdapat kontrol di dalamnya. Aturannya tetap ada walaupun bergeser dari dominasi negara kepada pertimbangan rasional etika moralitas, serta interaksi antar-institusi sosial (Subiakto \& Ida, 2012). Kebebasan pers bukan berarti bahwa pers boleh menyebarluaskan fitnah, kabar bohong, dan kebencian tetapi kebebasan pers tetap dibatasi oleh kebenaran dan kemerdekaan orang lain. Hal yang diungkap pers haruslah fakta (Subiakto \& Ida, 2012).

Hal serupa juga dikatakan oleh Ibrahim dan Akhmad bahwa media memiliki peran sosio-kultural sebagai cermin. Media tidak mencerminkan peristiwa secara netral dan secara sempurna. Media terlebih dahulu menyeleksi apa yang akan dimasukkan dalam berita (Ibrahim \& Akhmad, 2014).

Proses 'politik' yang dilakukan pihakpihak di balik media tampak kecenderungan pemanfaatan media sebagai mesin pembentuk opini rakyat. Media memanfaatkan fungsi sosialnya dalam menyebarkan informasi kepada masyarakat sekaligus untuk mengonstruksi pikiran-pikiran masyarakat mengenai sesuatu hal. Wacana merupakan kunci yang dikelola untuk menghasilkan suatu realitas sesuai dengan konteks ruang dan waktu. Wacana ini, seperti diartikan
Foucault, tidak lain merupakan: ...'a practice not just of representing the world, but of signifying the world, constituting and constructing the world in meaning' (Locke, 2004).

Wacana memiliki makna penting dalam pembentukan opini dalam masyarakat yang dalam oleh Fairclough dikatakan 'discourse(s) make the world meaningful', bahkan 'only in discourse is the world made meaningful. Wacana-wacana yang ada merupakan bentuk dari realitas sosial yang terjadi dalam masyarakat. Wacana-wacana inilah yang kemudian dimanfaatkan oleh media untuk menceritakan 'realitas sosial' yang terjadi dalam masyarakat, meskipun realitas sosial ini tidak selalu begitu adanya. Fairclough juga mengatakan bahwa wacana dibentuk oleh relasi kekuasaan dan ideologi yang berakibat pada identitas sosial, relasi sosial dan sistem pengetahuan serta kepercayaan (Fairclough, 1992).

Oleh karena itu, Fairclough menyebutkan bahwa ada tiga kontribusi wacana, yaitu: 1) Mengonstruksi identitas sosial dan posisi individu (subjek) untuk subjek sosial; 2) Membantu mengonstruksi hubungan sosial antar manusia; 3) Berkontribusi dalam membentuk sistem pengetahuan dan kepercayaan (Fairclough, 1992). Wacana pada akhirnya memberikan kontribusi yang besar terhadap pikiranpikiran atau pandangan dalam masyarakat. Wacana dianggap sebagai bagian dari realitas sosial yang terjadi dalam masyarakat sehingga keberadaan wacana dianggap selalu mengandung unsur 'kebenaran'.

Melalui wacana-wacana yang 'dibesarbesarkan' oleh media inilah, lambat laun terjadi konstruksi pemikiran dan pandangan yang relatif sama dalam masyarakat. Pengetahuan yang sama inilah yang kemudian bisa menjadi 'kebenaran baru' yang bisa saja realitasnya 'tidak benar'. Jika hal ini sudah terjadi, maka media berhasil 'mencuci otak masyarakat' dengan informasiinformasi yang mereka sebarkan sesuai dengan kepentingannya. Wacana inilah yang memainkan peran sentral dalam proses konstruksi realitas oleh media. Konstruksi realitas ini berlangsung dalam suatu situasi dan kondisi yang mendukung. 


\section{METODE PENELITIAN}

Penelitian ini menggunakan berita online sebagai bahan untuk mencari data. Berita online mampu memproduksi berita lebih banyak dibandingkan dengan berita dalam bentuk cetak maupun visual. Berita online mampu menghadirkan ratusan berita setiap harinya yang hanya berjarak sekitar 410 menit, terutama dalam kasus Pemilihan Presiden tahun 2014. Berita-berita online berlomba-lomba untuk memberikan berita yang paling aktual kepada pembacanya. Selain itu, membaca berita online bagi publik jauh lebih praktis dan menghemat biaya karena bisa dilakukan di mana saja dan kapan saja. Pemilihan ini juga dilandaskan pada suatu kecenderungan dinamis dari berita online untuk memperlihatkan bagaimana dinamika pemaknaan berlangsung dalam kehidupan masyarakat.

Dalam penelitian ini, berita online yang akan digunakan adalah detik.com dan okezone.com. Kedua media online ini adalah media online yang cukup besar dan diikuti jutaan pembaca setiap harinya. Kedua berita online ini memiliki kekuatan yang sangat besar untuk bisa memengaruhi pembaca. Akan tetapi, kedua berita online ini memiliki kecenderungan yang berbeda ketika mereka memberitakan informasi yang terkait dengan para capres. Berita yang digunakan adalah berita mulai tanggal 1 Juni 2014 - 9 Juli 2014. Tanggal 1 Juni 2014 merupakan tanggal ditetapkannya calon presiden dan wakil presiden secara resmi, sehingga mulai tanggal 1 Juni 2014 persaingan antar kedua calon sudah mulai bisa dirasakan. Sementara itu, tanggal 9 Juli 2014 adalah tanggal pemilihan presiden dan wakil presiden RI. Oleh karena itu, berita di antara tanggal 1 Juni- 9 Juli 2014merupakan berita yang berisi lebih banyak tentang proses politik di Indonesia sehingga bisa melihat keterlibatan kedua media ini dalam kurun waktu di atas.

Dalam mengambil data, penelitian ini menggunakan judul berita dalam detik.com maupun okezone.com. Judul berita sering kali bersifat provokatif dan berisi inti sari dari informasi yang akan dibaca sehingga terkadang tidak memerlukan membaca isi berita karena sudah terwakilkan melalui judul pemberitaan. Judul-judul ini kemudian dikelompokkan berdasarkan keterkaitan isu, misalnya pemberitaan yang berisi kampanye negatif terhadap lawan politik; wacana yang memperkuat karakter calon presiden sehingga dipandang baik oleh masyarakat; serta berita yang berisi pembelaan terhadap isu-isu atau wacana-wacana negatif dari lawan politik. Hasil dari pengumpulan judul pemberitaan dua berita online ini kemudian dianalisis.

Dalam penelitian ini yang diteliti adalah teks atau wacana yang dihasilkan oleh detik.com dan okezone.com. Teks menjadi penting dalam metode interpretasi karena teks adalah bagian yang bisa dianalisis ketika membaca dan memaknai teks sama dengan memaknai dan membaca kebudayaan yang ada (Geertz, 1992). Teks atau wacana yang diproduksi secara terus menerus akan menciptakan realitas atau kebenaran baru dalam masyarakat. Sehingga wacana-wacana yang dihadirkan oleh detik.com dan okezone.com mampu menjadi 'sumber kebenaran baru' bagi pembacanya.

Analisis data dilakukan dengan cara analisis konstruksi realitas menurut Berger dan Luckmann. Pertama, dengan mengangkat realitas-realitas yang ada dalam masyarakat. Tahapan ini merupakan proses eksternalisasi. Kedua, media memproduksi ulang realitas tersebut dengan penekanan-penekanan yang mereka berikan, memisahkan berita-berita yang dapat merugikan calon pilihannya, dan memberikan tambahan-tambahan wacana untuk meyakinkan pembaca bahwa calon pilihannyalah yang terbaik yang wacana baru itu kemudian menjadi realitas baru dalam masyarakat. Tahapan ini kemudian dikenal sebagai tahapan objektivasi. Ketiga, realitasrealitas baru ini perlu disosialisasikan dalam masyarakat sehingga media terus menerus memproduksi wacana yang sama setiap saat. Ini berguna agar masyarakat yakin atas pemberitaan-pemberitaan yang mereka baca setiap harinya (Berger \& Luckmann, 1991)

\section{HASIL PENELITIAN DAN PEMBAHASAN}

\section{Keterlibatan Media dalam Ranah Politik}

Media di Indonesia mau tidak mau, suka atau tidak suka harus melibatkan diri 
dalam proses politik di negeri ini. Selain politik merupakan salah satu realitas sosial yang hidup dalam bermasyarakat, politik merupakan cara untuk memperoleh kekuasaan. Orang-orang yang melihat kekuasaan sebagai jalan untuk menguasai negeri ini mulai berpikir untuk menarik simpati masyarakat. Salah satu cara yang cukup mudah adalah tampil di layar kaca untuk menaikkan popularitas. Seperti yang dilakukan oleh Susilo Bambang Yudhoyono (SBY) menjelang Pemilihan Presiden tahun 2004, beliau datang ke salah satu acara musik dan menyanyikan salah satu lagu (Junaedi, 2013). Cara ini kemudian efektif untuk menaikkan popularitas beliau.

Media massa mampu mengubah bentuk-bentuk marketing dalam dunia politik dari langsung menjadi melalui media massa (Utomo, 2013). Melemahnya kekuatan partai politik dan semakin berkembangnya media massa independen yang memungkinkan mereka membawa agendanya masing-masing Mancini dan Swanson dalam Utomo (2013b). Pada akhirnya, media menyadari bahwa pengaruh pemberitaan mereka bisa digunakan sebagai media komunikasi politik kepada masyarakat. Kondisi ini kemudian juga dipahami dengan baik oleh pemilik-pemilik media di Indonesia yang mayoritas terjun ke dunia politik.

Seperti Hary Tanoe yang memanfaatkan media miliknya untuk mempromosikan partai baru yang dia miliki, yaitu Partai Perindo. Begitu pula yang dilakukan oleh Abu Rizal Bakrie dan juga Surya Paloh. Politisi-politisi ini mampu menaikkan popularitas mereka dengan mudah karena mereka adalah pemilik media-media besar di Indonesia.

Pada akhirnya hanya dua calon presiden yang maju dalam pertarungan tahun 2014. Namun, hal ini bukan berarti pemilih-pemilik media ini bersikap netral dan tidak memiliki kepentingan pribadi. Mereka pada akhirnya juga menetapkan pilihan-pilihan politiknya, baik secara individu, pemilik media, ataupun sebagai ketua umum partai politik mereka. Seperti Abu Rizal Bakrie (ARB) yang merupakan ketua partai Golkar, pemilik media ANTV dan TV One menentukan pilihan politiknya untuk mendukung Prabowo sebagai presiden RI. Pilihan ARB ini kemudian juga memengaruhi pilihan media yang dimilikinya sehingga TV One menjadi salah satu basis terbesar media pendukung Prabowo. Begitu juga dengan Surya Paloh, pilihan politik partai politiknya (Nasional Demokrasi) menyebabkan media miliknya (Metro TV) merupakan basis terbesar media pendukung Jokowi.

Banyak fakta yang menunjukkan bahwa media tidak bisa bersikap netral atau tidak berpihak pada realitas-realitas politik yang ada karena pemilik-pemilik media itu sendiri adalah politisi yang memerlukan pemberitaan untuk membuat mereka dikenal oleh masyarakat ataupun memperkenalkan visimisi partai politik mereka. Keterlibatan media dalam politik di Indonesia begitu dalam sehingga sulit untuk melihat sikap netral mereka ataupun pilihan untuk tidak masuk ke ranah politik dan tetap memilih berjuang atas nama kepentingan rakyat.

\section{Kepentingan Media dalam Politik}

Terdapat berbagai kepentingan dalam diri media, mulai dari kepentingan ideologi, kepentingan politik, dan kepentingan pasar. Ini disebabkan posisi media yang independen, yaitu berdiri sendiri, bekerja untuk kepentingannya meskipun harus disadari bahwa media juga memiliki tanggung jawab moral untuk memberitakan realitas-realitas yang ada dalam masyarakat. Apalagi ketika media mulai dimiliki oleh swasta, sehingga keberpihakan media tidak lagi berpihak kepada kepentingan rakyat. Dengan sistem kepemilikan media seperti ini, maka media bisa memanfaatkan kekuatan yang dimilikinya untuk melakukan komodifikasi terhadap teks budaya, termasuk pesan-pesan politik dari organisasi politik (Junaedi, 2013).

Keterlibatan media yang begitu besar terjadi ketika Pemilihan Presiden tahun 2014. Media pendukung berusaha untuk memenangkan capres pilihannya. Pada saat yang sama ada media lain yang memberikan dukungan yang berbeda kepada calon presiden. Media-media ini bersaing, berusaha semaksimal mungkin memberitakan jagoannya untuk meraih simpati dari masyarakat. Pada saat itu, kepentingan rakyat serasa diabaikan. Rakyat tidak diberi kesempatan untuk berpikir agar bisa memilih 
dengan benar. Media sibuk menampilkan pencitraan-pencitraan politik. Mereka melakukan pemberitaan-pemberitaan positif dan menyangkal berita-berita negatif yang dapat merugikan calon pilihannya. Pada saat itu pula, pemberitaan yang diberikan oleh media terasa tidak mencerdaskan, dan bersifat subjektif.

Perlu disadari bahwa media tidak melakukan semua itu dengan gratis. Harus dibaca kepentingan media di balik semua 'sikap manisnya' terhadap capres pilihannya. Misalnya saja, Metro TV hanya menampilkan semua hal baik tentang Jokowi, dan beberapa berita mengenai Prabowo, meskipun berita yang mereka siarkan hanyalah berita-berita yang lebih banyak merugikan pihak Prabowo. Begitu pula sebaliknya, pihak TV One yang merupakan basis pertahanan Prabowo terhadap berita-berita buruk tentangnya. TV One juga merupakan salah satu produsen berita-berita positif mengenai Prabowo. Dari media televisi inilah, rakyat bisa mengenal pribadi Prabowo dengan lebih dekat. Isi pemberitaannya memanglah semua mengenai Prabowo, dari prestasi-prestasinya, langkah politik yang dibuat, visi-misi, dan lain sebagainya. Keberpihakan kedua media televisi ini membuahkan teguran dari Komisi Penyiaran Indonesia (KPI) kepada TV One dan Metro TV.

Metro TV adalah salah satu media swasta di Indonesia yang didirikan pada tahun 2000 di bawah kepemimpinan Surya Paloh. Media ini adalah media yang fokus pewartaannya pada berita. Surya Paloh adalah ketua Partai Nasional Demokrasi (NasDem) yang orientasi politiknya adalah berpihak kepada Jokowi. Seperti diketahui, JokowiJusuf Kalla (JK) bisa maju dalam pemilihan presiden karena didukung oleh empat partai, yaitu Partai Demokrasi Indonesia Perjuangan (PDIP), Partai Nasional Demokrasi (NasDem), Partai Hati Nurani Rakyat (Hanura), dan Partai Kebangkitan Bangsa (PKB). Peristiwa keterlibatan media seperti kasus ini, bisa dibaca bahwa Surya Paloh, sebagai salah satu ketua partai pendukung Jokowi-JK, memanfaatkan media yang dimilikinya untuk juga mendukung pencalonan Jokowi-JK untuk menjadi
Presiden dan Wakil Presiden Republik Indonesia 2014-2019.

Selain itu, juga bisa dilihat masa lalu Surya Paloh ketika masih berada di Partai Golkar. Beliau adalah salah satu tokoh terkuat yang bisa menjadi pemimpin Partai Golkar pada saat itu. Sayangnya, beliau kalah dengan Abu Rizal Bakrie (ARB) sehingga kemudian beliau membuat partainya sendiri untuk mengimbangi Partai Golkar di bawah kepemimpinan ARB. Peristiwa ini bisa dibaca bahwa Surya Paloh tidak bisa menerima kekalahan dan menjadi 'musuh' ARB, sehingga tidak salah ketika beliau mendapatkan kesempatan untuk memilih keberpihakan, beliau memilih calon yang bertentangan dengan ARB. Atau pun keterlibatan Metro TV pada pihak Jokowi-JK dikarenakan kedekatan personal Surya Paloh dengan JK. Pak Jusuf Kalla sendiri adalah salah satu mantan Ketua Umum Partai Golkar, kedekatan personal ini bisa saja terjalin dikarenakan mereka pernah berada pada satu partai yang sama.

Ketika membaca suatu peristiwa dengan cara menginterpretasikan terlebih dahulu, bisa dilihat realitas yang sebenarnya terjadi pada peristiwa tersebut. Seperti kasus di atas, keberpihakan Metro TV pada Jokowi-JK bisa dibaca sehingga muncul kepentingan media pendukung dikarenakan politik praktis pemilik media. Tidak hanya Metro TV, TV One pun melakukan hal yang sama. Sebagai salah satu pemilik TV One, ARB berhak menentukan arah politik media yang dimilikinya. Ketika orientasi politiknya berpihak kepada Prabowo, maka TV One seolah-olah adalah gerbang depan dalam pemberitaan mengenai Prabowo. Tidak hanya itu, vivanews.com, yang merupakan salah satu bisnis keluarga Bakrie, memiliki orientasi politik kepada Prabowo.

Selain kepentingan politik praktis pemilik media, kepentingan kedua yang mendasari keberpihakan media adalah kepentingan ideologis. Kepentingan ini sifatnya lebih mendasar dan tidak bersifat praktis. Misalnya saja keberpihakan media kepada pihak Jokowi dikarenakan media menganggap bahwa Prabowo adalah bagian dari Orde Baru. Prabowo adalah salah satu menantu dari mantan Presiden Soeharto yang 
pada masa pemerintahannya memberikan 'kenangan' buruk pada media di Indonesia. Media-media ini seperti memiliki ketakutan tersendiri apabila Prabowo menang menjadi Presiden Republik Indonesia. Mereka tidak menginginkan kebebasan dalam melakukan pemberitaan yang didapat dengan susahpayah akan kembali terkekang dengan terpilihnya Prabowo. Prabowo memang bagian dari keluarga Cendana pada waktu itu, basisnya adalah tentara, namun demikian belum dapat dikatakan bahwa Prabowo akan bersikap dan memiliki karakter politik yang serupa dengan Soeharto. Namun demikian, media membuat pilihan-pilihan tidak hanya bersifat ideologis tetapi juga praktis dan strategis bagi keberadaan media itu sendiri.

Kepentingan ketiga adalah kepentingan bisnis, yaitu keuntungan yang didapatkan oleh media ketika mereka mendukung salah satu capres. Hal ini karena biaya capres untuk melakukan 'promosi diri' tidaklah murah. Mereka memiliki anggaran yang cukup banyak agar masyarakat pada akhirnya memilih mereka. Untuk belanja iklan saja, Jokowi-JK dan Prabowo-Hatta menghabiskan dana sebesar Rp. 186.000.000.000. Riset menunjukkan, dari kubu Prabowo-Hatta, spot iklan TV bertajuk 'Garuda Merah' menjadi tema iklan yang banyak ditayangkan, dengan frekuensi tayang mencapai 725 kali. Sementara itu dari kubu Jokowi - JK, tema yang paling banyak ditayangkan adalah 'Siapkah Kita?,' yang mendapat porsi penayangan sebanyak 335 kali (Jatmiko, 2014).

Bisnis iklan pilpres tentu sangat menggiurkan bagi media. Mereka bisa meraih begitu banyak keuntungan dari bisnis yang hanya datang satu kali dalam lima tahun. Keterlibatan media pada tingkatan ini murni karena bisnis. Mereka tidak lagi memandang siapa yang mereka dukung karena yang paling penting bukanlah pilihan pada tataran ideologis maupun politik praktis tetapi keuntungan kapital dan laba yang mereka harapkan.

Kepentingan yang ada di balik media, mengaburkan 'cita-cita mulia' mereka untuk bekerja atas nama rakyat. Kebebasan pers yang didapatkan media setelah lama terkungkung pada masa Orde Baru pada akhirnya kalah dengan kepentingankepentingan praktis yang sangat menguntungkan media. Media merelakan dirinya 'dibayar' oleh pemilik modal dan pelaku politik untuk memuluskan kepentingan-kepentingannya. Hal ini yang telah membuat Chomsky memiliki kekhawatiran yang begitu besar. Menurutnya, media sudah menjadi bisnis baru yang mulai dikuasai oleh tokoh-tokoh yang memiliki senjata dan uang sehingga isi media diatur oleh para elite kekuasaan dan elite bisnis. Di sisi lain, atas nama pertumbuhan ekonomi, para pebisnis melakukan hal yang serupa (Subiakto \& Ida, 2012).

Dari berbagai penjabaran di atas, bisa diketahui bahwa media tidak lain adalah sebuah industri bisnis yang menggiurkan, terutama pada saat proses Pemilihan Presiden 2014. Media terlibat dalam proses politik karena ini adalah saat yang menguntungkan untuk mencari keuntungan, terlepas dari pemilik media yang mendukung salah satu calon presiden. Ini terbukti ketika 'kontrak' mereka habis dengan calon presiden, media bertindak netral dengan tidak lagi memberitakan mengenal calon tersebut.

Keterlibatan media dalam politik memang tidak selalu mengenai pilihan pribadi, mengingat bahwa di Indonesia pemilik media mayoritas adalah politisi aktif. Media tetaplah sebagai sebuah industri yang menginginkan keuntungan dari pemberitaan yang mereka lakukan. Sebagai industri, media tentu memiliki pelanggan yang ingin diberitakan baik oleh media (Sudibyo, 2001).

\section{Realitas Ala Detik.com dan Okezone.com}

Detik.com dan okezone.com merupakan media online yang memiliki cukup banyak pembaca. Detik.com telah berdiri sejak 30 Mei 1998, tetapi baru tanggal 9 Juli 1998 dapat diakses secara online. Pada Juli 1998 Begitu juga dengan okezone.com. Okezone.com resmi berdiri pada tanggal 29 Desember 2006 dan merupakan cikal-bakal bisnis online pertama milik PT (Anon, n.d.).

Mengikuti perkembangan pemberitaan yang dilakukan oleh detik.com dan okezone.com, akan diketahui dengan jelas bahwa detik.com adalah media online yang berpihak kepada Jokowi, begitu pula dengan 
okezone.com yang hampir seluruh pemberitaannya adalah mengenai Prabowo. Akan tetapi, ada fakta yang menarik mengenai kedua berita online ini, yaitu fokus berita (wacana) yang mereka besar-besarkan cukup berbeda. Di satu sisi, media ini bertugas untuk membentuk wacana-wacana baru dan meyakinkan masyarakat bahwa wacana yang mereka buat adalah sesuatu yang benar dan baik untuk masyarakat Indonesia. Di sisi yang lain, media ini juga merupakan alat untuk menjawab isu-isu yang merugikan calon presidennya.

Pemberitaan pada detik.com hanya menyangkut tiga hal. Pertama adalah berita tentang blusukan Jokowi. Kedua adalah pemberitaan pelanggaran HAM yang 'dianggap' dilakukan oleh Prabowo. Ketiga adalah Jokowi adalah bagian dari rakyat kecil sehingga mengerti betul apa yang diinginkan oleh rakyat.

Di lain sisi, okezone juga berisi mengenai tiga pemberitaan saja. Pertama, respons dalam menjawab tudingan-tudingan dari pihak Jokowi mengenai keterlibatannya dalam kasus 1998. Kedua adalah berita mengenai penciptaan sosok Prabowo. Dalam proses pembentukan sosok ini, Prabowo digambarkan sebagai sosok yang tegas, cinta tanah air, dan memiliki keinginan melihat rakyat Indonesia sejahtera. Ketegasan merupakan salah satu unsur yang ditekankan karena okezone ingin menyampaikan melalui wacananya bahwa ketegasan sangat diperlukan pemimpin untuk memimpin suatu bangsa. Ketiga, wacana yang berisi penolakan citra-citra baik mengenai Jokowi. okezone.com ingin menekankan bahwa halhal yang selama ini dilakukan oleh Jokowi hanya pencitraan semata. Oleh karena itu, okezone.com membuat berita mengenai Jokowi yang isinya tidak menguntungkan pihak Jokowi.

Untuk menjawab perbedaan dalam wacana yang dilakukan oleh kedua media ini, berita diperlakukan sebagai teks yang simbolsimbolnya harus dipahami dan dibandingkan dengan konteks yang berlaku.

Detik.com menganggap bahwa blusukan ala Jokowi masih sangat laku untuk bisa 'dijual' sebagai daya tarik masyarakat agar memilih Jokowi. Hal ini karena gaya blusukan Jokowi seperti membuka harapan baru bagi masyarakat Indonesia bahwa akan ada pemimpin yang mau memperhatikan rakyatnya. Gaya blusukan ini ternyata mampu 'membius' masyarakat Indonesia sehingga elektabilitas Jokowi sulit untuk dikalahkan. Gaya blusukan ini kemudian diberi penekanan wacana oleh media bahwa Jokowi adalah sosok yang peduli dengan kehidupan rakyat kecil. Ini dibuktikan dengan Jokowi dan JK menggunakan bajaj ketika datang ke gedung KPU untuk mengambil nomor (Ikhwanul, 2014).

Untuk melengkapi pemberitaannya, detik.com tidak hanya memberitakan berita mengenai Jokowi tetapi juga berita tentang Prabowo. Akan tetapi, pemberitaan mengenai Prabowo bukanlah berita yang menguntungkan. Pemberitaan yang dilakukan oleh detik.com mengenai Prabowo adalah pemberitaan keterlibatannya mengenai kasus pelanggaran HAM. Demikian pula dengan wacana kembali kepada pemerintahan Orde Baru dikatakan sebagai situasi yang akan terjadi jika Prabowo memimpin. Pemberitaan seperti ini bertujuan untuk 'merusak' reputasi Prabowo karena dianggap terlibat dalam penculikan tahun 1998 dan penerus Orde Baru. Kasus ini juga diharapkan bisa menjatuhkan pamor Prabowo sehingga rakyat tidak tertarik untuk memilihnya.

Tabel 1 adalah contoh pemberitaan yang dilakukan oleh detik.com yang menegaskan wacana bahwa Jokowi adalah sosok yang sederhana dan pro kepada rakyat miskin. Tabel 2 berisi berita mengenai blusukan yang dilakukan oleh Jokowi. Tabel 3 berisi tentang pemberitaan kasus HAM oleh Prabowo. Jika diperhatikan, detik.com lebih banyak memberitakan mengenai kasus HAM yang disinyalir ada keterlibatan Prabowo. Detik.com juga menghembuskan wacana baru yaitu jika Prabowo nanti menjadi presiden, maka kemungkinan besar sistem pemerintahan akan kembali seperti masa Orde Baru. 


\section{Tabel 1}

Pemberitaan detik.com yang Mewacanakan Jokowi sebagai Sosok Sederhana dan Mengerti Penderitaan Rakyat

\begin{tabular}{lc}
\hline \multicolumn{1}{c}{ Pemberitaan detik.Com } & Tanggal \\
\hline $\begin{array}{l}\text { Jokowi-JK Naik Bajaj, Prabowo-Hatta Pilih Naik Lexus ke KPU } \\
\text { (Ikhwanul, 2014) }\end{array}$ & 1 Juni 2014 \\
Jokowi: Yang di 'Sana' Kampanye di Hotel, Kalau Kita di Kampung \\
(Jordan, 2014a)
\end{tabular}

Tabel 2

Pemberitaan detik.com Mewacanakan Jokowi Pemimpin yang Hobi Blusukan

\begin{tabular}{lc}
\hline \multicolumn{1}{c}{ Pemberitaan detik.com } & Tanggal \\
\hline $\begin{array}{l}\text { Blusukan Adalah Konsep Mendengar Paling Jitu Ala Jokowi } \\
\text { (Taufiqqurahman, 2014) }\end{array}$ & 10 Juni 2014
\end{tabular}

Jokowi: Kalau Jadi Presiden Saya di Kantor Sejam, Selebihnya di Kampung

17 Juni 2014

(Nurbilkis, 2014)

Sumber: hasil penelitian

Tabel 3

Pemberitaan Detik.com Merugikan Prabowo

\begin{tabular}{lc}
\hline \multicolumn{1}{c}{ Pemberitaan detik.com } & Tanggal \\
\hline $\begin{array}{l}\text { Didukung Golkar dan Organisasi Sayapnya, Prabowo Bangkitkan Orde Baru? } \\
\text { (Dariyanto, 2014) }\end{array}$ & 4 Juni 2014 \\
$\begin{array}{l}\text { JK: Pilih Pemimpin yang Tidak Mempunyai Dosa Sosial } \\
\text { (Savitri, 2014) }\end{array}$ & 6 Juni 2014 \\
$\begin{array}{l}\text { Masa Lalu Prabowo Diungkit, Jokowi Dijadikan Kambing Hitam } \\
\text { (Sutrisno, 2014) }\end{array}$ & 12 Juni 2014 \\
$\begin{array}{l}\text { Buka-bukaan Wiranto Soal Keterlibatan Prabowo dalam Penculikan Aktivis } \\
\text { (Pratama, 2014) }\end{array}$ & 20 Juni 2014 \\
\hline
\end{tabular}

Sumber: Hasil Penelitian

Logika ini cukup masuk akal karena faktanya memang Prabowo adalah mantan menantu Soeharto. Wacana ini sengaja dihembuskan agar masyarakat Indonesia merasa takut akan pemerintahan yang otoriter seperti masa Orde Baru sehingga mereka tidak akan memilih Prabowo. Akan tetapi, isu ini kurang berkembang sehingga tidak dibesar-besarkan oleh detik.com. Mereka lebih memilih untuk memberitakan mengenai kasus HAM yang 'melibatkan' Prabowo. Meskipun untuk itu mereka harus cukup adil dalam pemberitaan, mengambil berita yang menguntungkan pihak Jokowi dan juga memberikan kesempatan kepada pihak Prabowo untuk meluruskan permasalahan ini.
Jokowi sendiri sudah sangat populer dengan sosok blusukan dan 'kesederhanaannya' yang sejak awal menjadi fokus media sehingga detik.com sebagai media pendukung Jokowi tidak perlu bersusah-payah untuk melakukan 'pembentukan tokoh' Jokowi. Kepopulerannya ini juga yang menyebabkan Megawati, sebagai Ketua Umum Partai pendukung Jokowi, memberikan kesempatan kepada Jokowi untuk maju menjadi calon presiden dengan kemungkinan menang yang sangat besar. Di sisi lain, jika Megawati sendiri maju menjadi calon presiden, banyak pengamat menyatakan keraguan untuk bisa menang. 
Jokowi mendapatkan dukungan masyarakat luas bukan hanya berasal dari partai pendukungnya. 'Massa' Jokowi ini adalah massa lepas, sebagian besar dari mereka tidak bergabung dalam organisasi yang dukungannya diberikan secara formal kepada Jokowi. Mereka adalah orang-orang yang berada di luar struktur keorganisasian sehingga jumlah mereka tidak bisa diketahui dengan pasti. Untuk itu, Jokowi memberikan wadah bagi massa lepas ini dengan label relawan Jokowi. Relawan inilah yang kemudian bekerja memberikan dukungan penuh kepada Jokowi, baik secara langsung maupun dalam dunia maya. Di sisi lain, media pendukung Prabowo, khususnya okezone.com bekerja ekstra untuk membentuk 'sosok Prabowo' menjadi sosok yang layak dipilih. Okezone.com juga menjadi benteng pertahanan Prabowo untuk menjawab isu-isu negatif seputar Prabowo, seperti isu tentang HAM dan Orde Baru. Tuduhan-tuduhan ini secara tidak langsung juga mengingatkan masyarakat Indonesia siapa sosok Prabowo sebenarnya dan juga mengingatkan mereka mengenai kedekatan Prabowo dengan mertuanya, Soeharto. Masyarakat Indonesia seperti memiliki trauma masa lalu dengan pemerintahan Soeharto yang dikesankan otoriter dan bertentangan dengan reformasi yang sekarang ini mereka nikmati.

Melihat adanya berita yang merugikan Prabowo, membuat media pendukungnya melakukan pertahanan dan pembelaan untuk membersihkan nama baik Prabowo. Okezone memberikan banyak berita yang bertolak belakang dengan pemberitaan yang diberikan oleh detik.com, seperti: "Lulus Seleksi KPU, Prabowo Terbukti Bukan Pelanggar HAM"; "Prabowo: Orde Baru Sudah Lewat";
"Marwah Daud: 1998 Prabowo Tidak Bersalah!"; "Fakta Prabowo Bukan Inisiator Penculikan Aktivis"; dan "Fadli: Prabowo Itu Orde Bangkit Bukan Orba". Selain itu, okezone.com juga melakukan pemberitaan mengenai Jokowi meskipun mayoritas adalah berita yang merugikan pihak Jokowi.

Membaca berita-berita yang dimuat dalam okezone.com, ada tiga poin penting yang mereka tekankan. Pertama adalah pembelaan-pembelaan dalam rangka membersihkan nama baik prabowo. Detik.com menggunakan isu pelanggaran ham dan isu kebangkitan Orde Baru untuk menjatuhkan nama baik Prabowo. Di sinilah berita-berita mengenai "fakta lain" versi okezone.com disebarluaskan. okezone.com memberikan wacana tandingan mengenai fakta-fakta bahwa Prabowo tidak terkait dengan kasus pelanggaran HAM yang dituduhkan kepadanya. pada poin pertama ini, okezone.com juga membela Prabowo bahwa tidak mungkin Prabowo membangkitkan Orde Baru kembali.

Poin kedua adalah pembentukan wacana baru dalam masyarakat bahwa masyarakat Indonesia membutuhkan sosok pemimpin yang tegas, tidak mencla-mencle. Ketegasan diperlukan pemimpin untuk tidak ragu-ragu ketika mengambil keputusan. Wacana ini diperkuat dengan wacana lain yang mengatakan bahwa Prabowo adalah sosok yang sangat nasionalis dan mencintai negaranya sehingga tidak akan beliau biarkan 'asing' menguasai negaranya. Sosok seperti Prabowo lah yang pantas untuk memimpin negeri ini. Poin ketiga adalah okezone berusaha menepis wacana-wacana positif yang diciptakan media pendukung Jokowi yaitu blusukan.

Tabel 4

Pemberitaan Okezone.com untuk Menepis Isu pelanggaran HAM

\begin{tabular}{lc}
\multicolumn{1}{c}{ Pemberitaan okezone.com } & Tanggal \\
\hline $\begin{array}{l}\text { Isu HAM Takkan Menurunkan Elektabilitas Prabowo } \\
\text { (Firdaus, 2014) }\end{array}$ & 1 Juni 2014 \\
$\begin{array}{l}\text { Lulus Seleksi KPU, Prabowo Terbukti Bukan Pelanggar HAM } \\
\text { (Munir, 2014) }\end{array}$ & 2 Juni 2014 \\
$\begin{array}{l}\text { Masyarakat Sudah Bosan dengan Isu HAM yang Menyerang Prabowo } \\
\text { (Diputra, 2014b) }\end{array}$ & 14 Juni 2014 \\
Fadli: Prabowo Itu Orde Bangkit Bukan Orba (Anon, 2014) & 2 Juli 2014 \\
\hline
\end{tabular}

Sumber: hasil Penelitian 
Tabel 5

Pemberitaan Okezone.com dalam Rangka Pembentukan Sosok Prabowo

Prabowo Leader, Jokowi Manajer (Aisyah, 2014c)

Indonesia Butuh Pemimpin Tegas, Bukan yang Sibuk Pencitraan

(Fardiansyah, 2014a)

Rakyat Lebih Butuh Pemimpin Tegas daripada Merakyat

(Setyadi, 2014)

Prabowo Lebih Soekarnois Ketimbang Jokowi

(Fardiansyah, 2014b)

Sumber: Hasil Penelitian
10 Juni 2014

12 Juni 2014

29 Juni 2014

3 Juli 2014

Tabel 6

Pemberitaan Okezone.com mengenai Jokowi

\begin{tabular}{lc}
\hline \multicolumn{1}{c}{ Pemberitaan okezone.com } & Tanggal \\
\hline Disebut Boneka karena Jokowi Salah Tingkah di Depan Mega (Hidayat, & 3 Juni 2014 \\
2014) & \\
Capres Naik Bajaj Dinilai Pencitraan Berlebihan (Aisyah, 2014b) & 4 Juni 2014 \\
Capres \& Cawapres Jangan Pura-Pura Merakyat (Aisyah, 2014a) & 4 Juni 2014 \\
Gaya Jokowi Naik Bajaj Bisa Jadi Bahan Guyonan (Diputra, 2014a) & 5 Juni 2014 \\
\hline
\end{tabular}

Sumber: Hasil Penelitian

Okezone memberikan berita-berita yang mereka anggap 'fakta' bahwa blusukan yang dilakukan oleh Jokowi adalah salah satu bentuk pencitraan semata. Wacana yang dihadirkan kemudian oleh okezone.com adalah masyarakat Indonesia tidak butuh pemimpin yang hanya sibuk pencitraan saja tetapi sosok yang 'asli'.

\section{PENUTUP}

\section{Simpulan}

Kasus Pemilihan Presiden 2014, menjadi bukti empiris keberpihakan media yang ditentukan oleh orientasi politik atau kepentingan pemilik media. Pemilik media sebagian besar seorang politisi, yang selain mendapatkan keuntungan politik sebagai orang yang mendukung salah satu calon, mereka juga mendapatkan keuntungan kapital dari pemberitaan-pemberitaan serta iklan yang ditayangkan di media mereka.

Serupa dengan media yang lain, okezone dan detik.com juga terlibat pada proses Pemilihan Presiden tahun 2014. Kedua media online ini merupakan media pendukung calon presiden yang memberikan perhatian khusus pada perkembangan politik, sampai-sampai kedua media ini memberikan satu ruang khusus yang berisi perkembangan politik Indonesia setiap beberapa menit. Perbedaannya terletak pada orientasi politik yang mana detik.com mendukung Jokowi dan okezone.com mendukung Prabowo.

Proses konstruksi realitas yang diciptakan oleh media pada dasarnya diarahkan pada pilihan-pilihan politik masyarakat agar sejalan dengan yang diinginkan oleh media. Di satu sisi, pilihanpilihan politik masyarakat sangat dipengaruhi oleh pilihan-pilihan politik media yang diikutinya. Di sisi lain, pilihan-pilihan politik media merupakan pilihan politik pemilik media yang memiliki kepentingan politiknya sendiri. Lebih jauh lagi, kepentingan media di Indonesia mengikuti kepentingan pemilik modal, orang yang membayar mereka untuk melakukan konstruksi atas realitas dalam masyarakat. Itu artinya proses pemilihan presiden di Indonesia memang dilakukan oleh rakyat tetapi pilihan-pilihan rakyat tidaklah bebas dari pengaruh luar, pengaruh media, pengaruh aktor di balik media, serta ideologi yang melatarbelakanginya.

\section{Saran}

Media merupakan salah satu pusat informasi yang dimiliki oleh pembaca. Setiap informasi yang dihadirkan mampu memberikan kontribusi terhadap opini publik. Media seharusnya mampu menjadi agen yang netral serta mampu menampung aspirasi rakyat serta memberikan informasi yang berimbang. Terutama ketika informasi di 
dunia maya terlalu banyak sehingga pembaca tidak bisa membedakan mana yang benar dan mana yang hoaks. Berita online yang dihadirkan oleh media-media terpercaya sebaiknya mampu menjadi penyeimbang bukan sebagai agen yang memihak apalagi turut serta dalam menyebarkan informasiinformasi yang bisa menyesatkan publik.

\section{DAFTAR PUSTAKA}

Aisyah (2014a) Capres \& Cawapres Jangan Pura-Pura Merakyat. [Online]. 2014. Okezone.Com. Available from: http://pemilu.okezone.com/read/2014/06/04/ 568/993644/capres-cawapres-jangan-purapura-merakyat [Accessed: 6 June 2014].

Aisyah (2014b) Capres Naik Bajaj Dinilai Pencitraan Berlebihan. [Online]. 2014. Okezone.Com. Available from: http://pemilu.okezone.com/read/2014/06/04/ 567/993648/capres-naik- bajaj-dinilaipencitraan-berlebihan [Accessed: 6 June 2014].

Aisyah (2014c) Prabowo Leader, Jokowi Manajer. [Online]. 2014. Okezone.com. Available from: http://pemilu.okezone.com/read/2014/06/10/ 567/996551/prabowo-leader-jokowi-manajer [Accessed: 13 June 2014].

Anon (n.d.) ABOUT US OKEZONE.COM. [Online]. Okezone.com. Available from: https://management.okezone.com/ [Accessed: 3 July 2014].

Anon (2014) Fadli: Prabowo Itu Orde Bangkit Bukan Orba. [Online]. 2014. Available from:

http://pemilu.okezone.com/read/2014/07/02/ 567/1007034/fadli-prabowo-itu-ordebangkit-bukan-orba [Accessed: 5 July 2014].

Arifin, A. (2014) Politik Pencitraan: Pencitraan Politik. Yogyakarta, Graha Ilmu.

Berger, P.L. \& Luckmann, T. (1991) The Social Construction of Reality: A Treatise in The Sociology of Knowledge. New York, Penguin Book.

Dariyanto, E. (2014) Didukung Golkar dan Organisasi Sayapnya, Prabowo Bangkitkan Orde Baru? [Online]. 2014. Available from: https://news.detik.com/berita/d-

2599521/didukung-golkar-dan-organisasisayapnya-prabowo-bangkitkan-orde-baru [Accessed: 10 June 2014].

Diputra, R. (2014a) Gaya Jokowi Naik Bajaj Bisa Jadi Bahan Guyonan. [Online]. 2014.
Okezone.Com. Available from: http://pemilu.okezone.com/read/2014/06/04/ 567/994144/gaya-jokowi-naik- bajaj-bisajadi-bahan-guyonan [Accessed: 5 June 2014].

Diputra, R. (2014b) Masyarakat Sudah Bosan dengan Isu HAM yang Menyerang Prabowo. [Online]. 2014. Okezone.Com. Available from:

http://pemilu.okezone.com/read/2014/06/14/ 567/998691/masyarakat-sudah- bosandengan-isu-ham-yang-menyerang-prabowo [Accessed: 14 June 2014].

Fairclough, N. (1992) Discourse and Social Change. Cambridge, Polity Press.

Fardiansyah, A. (2014a) Indonesia Butuh Pemimpin Tegas, Bukan yang Sibuk Pencitraan. [Online]. 2014. Available from: http://pemilu.okezone.com/read/2014/06/12/ 567/997863/indonesia-butuh-pemimpintegas-bukan-yang-sibuk-pencitraan [Accessed: 14 June 2014].

Fardiansyah, A. (2014b) Prabowo Lebih Soekarnois Ketimbang Jokowi. [Online]. 2014. Available from: http://pemilu.okezone.com/read/2014/07/03/ 567/1007427/prabowo-lebih-soekarnoisketimbang-jokowi [Accessed: 3 July 2014].

Firdaus, F. (2014) Isu HAM Takkan Menurunkan Elektabilitas Prabowo. [Online]. 2014. Available from: http://pemilu.okezone.com/read/2014/06/01/ 567/992524/isu-ham-takkan-menurunkanelektabilitas-prabowo [Accessed: 1 June 2014].

Geertz, C. (1992) Tafsir Kebudayaan. Yogyakarta, Kanisius.

Hidayat, Q. (2014) Disebut Boneka karena Jokowi Salah Tingkah di Depan Mega. [Online]. 2014. Available from: http://pemilu.okezone.com/read/2014/06/03/ 567/993167/disebut-boneka-karena-jokowisalah-tingkah-di-depan-mega [Accessed: 3 June 2014].

Ibrahim, I.S. \& Akhmad, B.A. (2014) Komunikasi \& Komodifikasi: Mengkaji Media dan Budaya dalam Dinamika Globalisasi. Jakarta, Yayasan Pustaka Obor Indonesia.

Ikhwanul, K. (2014) Jokowi-JK Naik Bajaj, Prabowo-Hatta Pilih Naik Lexus ke KPU. [Online]. 2014. Available from: http://news.detik.com/read/2014/06/01/1357 21/2596473/1562/jokowi-jk-naik-bajajprabowo-hatta-pilih-naik-lexus-ke-kpu [Accessed: 1 June 2014].

Jatmiko, B.P. (2014) Belanja Iklan TV Selama Kampanye Pilpres Capai Rp 186 Miliyar. 
[Online]. 2014. Available from: http://bisniskeuangan.kompas.com/read/201 4/07/10/172838026/Belanja.Ikla [Accessed: 12 July 2014].

Jordan, R. (2014a) Jokowi: Yang di "Sana" Kampanye di Hotel, Kalau Kita di Kampung. [Online]. 2014. Available from: http://news.detik.com/read/2014/06/05/1050 39/2600480/1562/jokowi-yang-di-sanakampanye-di-hotel-kalau-kita-di-kampung [Accessed: 5 June 2014].

Jordan, R. (2014b) Pernah Tinggal di Bantaran Kali, Jokowi Mengaku Mengerti Penderitaan Rakyat. [Online]. 2014. Available from: http://news.detik.com/read/2014/06/05/1925 46/2601270/1562/pernah-tinggal-dibantaran-kali-jokowi-mengaku-mengertipenderitaan-rakyat [Accessed: 6 June 2014].

Junaedi, F. (2013) Komunikasi Politik: Teori, Aplikasi dan Strategi di Indonesia. Yogyakarta, Buku Litera.

Locke, T. (2004) Critical Discourse Analysis (Continuum Research Methods). London and New York, Continuum International Publishing Group.

Lubis, A.Y. (2014) Postmodernisme: Teori dan Metode. Jakarta, Rajawali Press.

Munir, M. (2014) Lulus Seleksi KPU, Prabowo Terbukti Bukan Pelanggar HAM. [Online]. 2014. Available from: http://pemilu.okezone.com/read/2014/06/02/ 567/992964/lulus-seleksi-kpu-prabowoterbukti-bukan-pelanggar-ham [Accessed: 3 June 2014].

Nugroho, B.R. (2014) Jokowi Beli Baju Kotakkotak Rp 75.000 dan 2 Pasang Sepatu di ITC Depok. [Online]. 2014. Available from: http://news.detik.com/read/2014/07/04/1606 14/2628107/1562/jokowi-beli-baju-kotakkotak-rp-75000-dan-2-pasang-sepatu-di-itcdepok [Accessed: 6 July 2014].

Nurbilkis, M. (2014) Jokowi: Kalau Jadi Presiden Saya di Kantor Sejam, Selebihnya di Kampung. [Online]. 2014. Available from:

http://news.detik.com/read/2014/06/17/1559 17/2610676/1562/jokowi-kalau-jadipresiden-saya-di-kantor-sejam-selebihnyadi-kampung [Accessed: 18 June 2014].

Pratama, F. (2014) Buka-bukaan Wiranto Soal Keterlibatan Prabowo dalam Penculikan Aktivis. [Online]. 2014. Detik.Com. Available from: http://news.detik.com/read/2014/06/20/0709 07/2613789/1562/buka-bukaan- wiranto- soal-keterlibatan-prabowo-dalam-

penculikan-aktivis [Accessed: 21 June 2014].

Savitri, A.W. (2014) JK: Pilih Pemimpin yang Tidak Mempunyai Dosa Sosial. [Online]. 2014. detik.com. Available from: http://news.detik.com/berita/2601892/jkpilih-pemimpin-yang-tidakmempunyaidosa-sosial [Accessed: 7 June 2014].

Setyadi, A. (2014) Rakyat Lebih Butuh Pemimpin Tegas daripada Merakyat. [Online]. 2014. Available from: http://pemilu.okezone.com/read/2014/06/29/ 567/1005734/rakyat-lebih-butuh-pemimpintegas-daripada-merakyat [Accessed: 30 June 2014].

Subiakto, H. \& Ida, R. (2012) Komunikasi Politik, Media dan Demokrasi. Jakarta, Kencana Prenada Media Group.

Sudibyo, A. (2001) Politik Media dan Pertarungan Wacana. Yogyakarta, LKiS Pelangi Aksara.

Sutrisno, E.D. (2014) Masa Lalu Prabowo Diungkit, Jokowi Dijadikan Kambing Hitam. [Online]. 2014. Available from: http://news.detik.com/read/2014/06/12/1031 04/2606015/1562/dilema-prabowo-hadapibayang-bayang-masa-lalu [Accessed: 12 June 2014].

Syahputra, I. (2012) Rezim Media: Pergulatan Demokrasi, Jurnalisme, dan Infotainment dalam Industri Televisi. Jakarta, Gramedia Pustaka Utama.

Taufiqqurahman, M. (2014) Blusukan Adalah Konsep Mendengar Paling Jitu Ala Jokowi. [Online]. 2014. Available from: http://news.detik.com/read/2014/06/10/2026 28/2604608/1562/blusukan-adalah-konsepmendengar-paling-jitu-ala-jokowi [Accessed: 11 June 2014].

Utomo, W.P. (2013) Menimbang Media Sosial dalam Marketing Politik di Indonesia: Belajar dari Jokowi-Ahok di Pilkada DKI Jakarta 2012. Jurnal Ilmu Sosial dan Ilmu Politik. [Online] 17 (1), 67-84. Available from:

https://jurnal.ugm.ac.id/jsp/article/view/108 94.

Wardah, F. (2014) 6 Parpol Dukung Pasangan Prabowo-Hatta dalam Pilpres. [Online]. 2014. voaindonesia.com. Available from: https://www.voaindonesia.com/a/parpoldukung-pasangan-prabowo-hatta-dalampilpres/1917769.html [Accessed: 22 May 2018]. 